\title{
Study of 24 Hours/2 day Monitoring of Blood Pressure in Subjects with Traumatic Paraplegia
}

\author{
Vandana Chaudhary, Narsingh Verma, Sunita Tiwari, R. N. Srivastava, and Dileep Verma
}

\section{ABSTRACT}

Cardiovascular dysfunction and cognitive decline are more common in traumatic spinal cord injury (SCI). Most people with a cervical or upperthoracic SCI usually experience conditions called orthostatic hypotension and autonomic dysreflexia, which are described by the serious changes in systemic blood pressure. To evaluate baseline heart rate (HR), baseline blood pressure (BP) and ABPM monitoring in traumatic paraplegia patients. In this study, total 36 diagnosed of paraplegia patients was based on Asia Impairment Scale (AIS), paralysed by RTA, or fall from height within 7 days of injury were included in this study. The blood pressure was monitoring for 24 hour/2 day and repeated after $12^{\text {th }}$ day of first monitoring. Ambulatory blood pressure was monitored by ABPM machine at HALF hourly from $6 \mathrm{am}-10 \mathrm{pm}$ and one hourly from $10 \mathrm{pm}-6 \mathrm{am}$. All the continuous variables were compared by $t$ - test. The night dipping (Systole) and morning surge (Systole) were significantly lower at $12^{\text {th }}$ days as compared to within 7 Days $(\mathbf{p = 0 . 0 0 2})$. Whereas the diurnal Index (Diastole) and diurnal Index (MAP) were comparable in between within 7 days and $12^{\text {th }}$ days. The mean SBP max and SBP min were significantly lower at $12^{\text {th }}$ day as compared to within 7 days. Whereas DBP max and min were comparable in between within 7 days and at $12^{\text {th }}$ days. The changes in min., max and mean double product (All, active periods, and passive periods) were also not found to be statistically significant in between within 7 days and at $12^{\text {th }}$ day. The traumatic paraplegic patients have altered diurnal index, morning surge, night dipping and systolic blood pressure on APBM monitoring.

Keywords: Paraplegic, Heart rate, Blood pressure, Trauma, Spinal cord injury.
Submitted : April 29, 2021

Published : July 14, 2021

ISSN: $2593-8339$

DOI: 10.24018 / ejmed.2021.3.4.837

\section{Vandana Chaudhary}

Junior Resident III, Department of Physiology, King Georges Medical University, Lucknow, India.

(e-mail: vandana6aug@gmail.com)

Narsingh Verma*

Professor, Department of Physiology,

King Georges Medical University, Lucknow, India.

(e-mail: narsinghverma ${ }^{@}$ gmail.com) Sunita Tiwari

Professor \& Head, Department of Physiology, King Georges Medical University, Lucknow, India.

(e-mail: sunita_kgmu@yahoo.com)

R. N. Srivastava

Professor, Department of Orthopaedics, King Georges Medical University, Lucknow, India.

(e-mail: drrnsrivastava ${ }^{\circledR}$ yahoo.com) Dileep Verma

Professor, Department of Physiology, King Georges Medical University, Lucknow, India.

(e-mail:

dileepverma200131@ rediffmail.com)

*Corresponding Author

\section{INTRODUCTION}

The traumatic spinal cord injury can cause sensory, motor just as autonomic weakness prompts cardiovascular system dysfunction as a result of the disturbance in the autonomic nervous pathways, leading to complications such as orthostatic hypotension $(\mathrm{OH})$ and autonomic dysreflexia (AD) [1]-[3]. The cardiovascular disease (CVD) has become a significant wellspring of morbidity and mortality in spinal cord injury individuals [4], [5]. Within the sight of relentless hypotension and orthostatic hypotension show as surprising changes in blood pressure and heartbeat rate, can cause a scope of signs that may provoke limitations in activities the of day by day living or serious clinical and neurological results [6]. The level of injury may increase the risk of CVD such as the impairment in autonomic regulation of cardiovascular that causes instability in blood pressure (BP) [7], [8]. Furthermore, to these variations in blood pressure and heart rate, the deficiency of thoughtful information is additionally connected with diminished diurnal variety in BP relying upon the level and seriousness of injury [1], [9].

Worldwide, the of spinal card injury (SCI) range from 40 to $80 \mathrm{cases} / \mathrm{million}$ yearly [10]-[12]. The SCI included the functional disability, loss of autonomy, mortality, morbidity, and great lifetime costs, including the criticalness of limiting the course of damage to the microenvironment around the injury [13].

The ambulatory blood pressure monitoring (ABPM) is a valuable tool monitor circadian BP profiles, which have been demonstrated to be of acceptable prognostic incentive for cardiovascular bleakness and mortality in physically fit [14]. 
The central nervous system (CNS) is a crucial part of the body which contains brain and spinal cord. The spinal cord is a thick long structure made up of nervous tissue which extends caudally and is protected by the surrounding (CSF) cerebral spinal fluid and bony vertebra column which prevents the fragile nerve tissue [15], [16]. The nerves connecting the spinal cord to the body are called the Peripheral Nervous System. Any trauma of spinal cord can affect conduction of both sensory and motor signals across the site(s) of lesion(s), as well as the autonomic nervous system. By doing systematic examination the dermatomes and myotomes, we can determine the cord segments affected by the SCI [5]. In this study we aim to evaluate the increasing risk of developing cardiovascular morbidity and mortality in traumatic paraplegia patients.

\section{MATERIAL AND MethodS}

This cross-sectional study was carried out in spinal injury unit of Orthopaedic department, King Georges Medical University; Lucknow after getting approval from Ethical committee of King Georges Medical University, Lucknow (Ref. code $-96^{\text {th }}$ ECM II B - Thesis/P28). Total 36 patients paralysed by RTA or fall from height within 7 days of injury were included in this study. Patients with $>70$ yrs, unconscious, any spinal tumor and other known endocrinal and cardiovascular disease non traumatic paraplegia and other known neurological deficit were excluded from the study Informed written consent was obtained from each patient on the prescribed consent form.

Diagnosis of paraplegia patients was based on Asia Impairment Scale (AIS); Motor function grading and sensory grading [17], [18]. The cases were diagnosed on the basis of presenting symptoms of the patient (Table I).

Differentiation between complete and incomplete paraplegia was done by clinical sensory and motor examination. The patient usually suffers from loss of sensation, loss of mobility and variability in blood pressure. Other common symptoms are respiratory insufficiency, inhibition of bladder and bowel movement, urinary retention, and abdominal pain.

A comprehensive history was carefully obtained with special reference to their past medical history, personnel history. Also, history of dietary, smoking, alcohol and any kind of substance abuse were recorded. A quick general physical examination including blood pressure, pallor, icterus, lymphadenopathy, bed sore was performed. To rule out any systemic illness, a quick systemic examination of respiratory, abdominal, cardiovascular, system was also carried out. Detailed Neurological examination was performed which includes sensory examination and motor examination and this examination was repeated again before discharge of patient.

The recruited subject within 7 days of their paraplegia was subjected to blood pressure monitoring for 24 hour/2day while they are admitted in the traumatic paraplegia wards in Orthopaedics department. The blood pressure monitoring was repeated after $12^{\text {th }}$ day of first monitoring. Both set of data was subjected to COSINOR analysis software and they were compared to find out statistical significance. Ambulatory blood pressure was monitored by ABPM machine at HALF hourly from $6 \mathrm{am}-10 \mathrm{pm}$ and ONE hourly from 10pm - $6 \mathrm{am}$.

\section{A. Statistical Analysis}

The sample size was calculated on the basis of SD's of SBP in Tetraplegics and paraplegics with 90 per cent of power and 95\% confidence level. [20] The data is expressed as mean, standard deviation (SD) and percentage as appropriate. All the continuous variables in two groups were compared by t- test. The p-value $<0.05$ was considered as significant. The statistical analysis was done using SPSS 23.0 version (Chicago, Inc., USA) windows software.

\section{RESULTS}

The mean $\pm \mathrm{SD}$ age (years) of the patients were $33.79 \pm 11.05$, gender. Among all the subjects, males were in majority with $27(79.41 \%)$ proportion and rest 7 (20.59\%) were females. Most of the subjects were laborers (47.1\%) while among women majority were housewives (14.7\%). Students were $14.7 \%$. Fall from height was the major mode of injury which was observed in $44.1 \%$ cases. RTA was the second most common mode of injury which was observed in $20.6 \%$ cases. Other mode of injuries was fall from tree $(17.6 \%)$, fall of heavy object $(8.8 \%)$, fall from stairs $(5.9 \%)$ and fall from bike (2.9\%). The AIS grades A, B, C and E were found in proportion $70.6 \%, 20.6 \%, 5.9 \%$ and $2.9 \%$ respectively in the study. The involuntary BBI was found in $88.2 \%$ cases while voluntary BBI was found in $11.8 \%$ cases. The most frequently neurological injury was L1 which was observed in $15(44.1 \%)$ cases separately and combined with $\mathrm{T} 12$ in one case. Other frequent injuries were T10 (14.7\%), $\mathrm{T} 12(11.8 \%+2.9 \%$ with L1), T11 (8.8\%) etc. Among the total 34 injuries, $22(64.7 \%)$ were of the complete nature while 12 $(35.3 \%)$ were of the incomplete nature (Table II).

Changes in Diurnal Index (Diastole), Diurnal Index (MAP), night dipping (Systole) and Morning Surge (Systole) from within 7 days to at $12^{\text {th }}$ day. The mean value of Diurnal Index (Diastole) within 7 days was $3.76 \pm 3.64$ which was changed to the mean $2.35 \pm 5.22$ at $12^{\text {th }}$ day. The mean value of Diurnal Index (MAP) within 7 days was $3.26 \pm 2.96$ which was changed to the mean $2.26 \pm 4.19$ at $12^{\text {th }}$ day. The mean value of night dipping (Systole) within 7 days was which was changed to the mean at $12^{\text {th }}$ day. The mean value of Morning Surge (Systole) within 7 days was $5.24 \pm 6.32$ which was changed to the mean $0.56 \pm 5.05$ at $12^{\text {th }}$ day. Moreover, the night dipping (Systole) and morning surge (Systole) were significantly lower at $12^{\text {th }}$ Day as compared to within 7 days $(\mathrm{p}=0.002)$. Whereas the diurnal Index (Diastole) and diurnal Index (MAP) were comparable in between within 7 days and $12^{\text {th }}$ days (Table III).

Comparison DBP (Max), DBP (min.), SBP (Max) and SBP (Min) in between within 7 days and at $12^{\text {th }}$ day. The mean value of DBP (Max) within 7 days was $77.38 \pm 9.12 \mathrm{mmHg}$ which was changed to the mean $77.15 \pm 9.92 \mathrm{mmHg}$ at $12^{\text {th }}$ day. The mean value of SBP (Max) within 7 days was $124.74 \pm 14.78 \mathrm{mmHg}$ which was changed to the mean $118.59 \pm 14.44 \mathrm{mmHg}$ at $12^{\text {th }}$ day. The mean value of DBP (Min) within 7 days was $62.38 \pm 9.44 \mathrm{mmHg}$ which was changed to the mean $61.44 \pm 9.17 \mathrm{mmHg}$ at $12^{\text {th }}$ day. The mean value of SBP (Min) within 7 days was $105.26 \pm 13.43 \mathrm{mmHg}$ which was changed to the mean $100.06 \pm 9.89 \mathrm{mmHg}$ at $12^{\text {th }}$ day. The mean SBP max and SBP min were significantly lower at $12^{\text {th }}$ day as compared to within 7 days. Whereas DBP 
max and min were comparable in between within 7 days and at $12^{\text {th }}$ day (Table IV).

Changes in min., max., and mean Double Product (All, active periods, and Passive Periods). The mean value of Double Product (All) Min within 7 days was $7231.76 \pm 1595.19$ which was changed to the mean $7473.00 \pm 1452.44$ at $12^{\text {th }}$ day. The mean value of Double Product (All) Max within 7 days was 13104.85 \pm 3046.42 which was changed to the mean $13224.53 \pm 3100.06$ at $12^{\text {th }}$ day. The mean value of Double Product (All) Mean within 7 days was $9761.65 \pm 9831.82$ which was changed to the mean $9831.82 \pm 1693.83$ at $12^{\text {th }}$ day. The changes in min., max and mean double product (all) were not found to be statistically significant in between within 7 days and at $12^{\text {th }}$ day (Table V).

The mean value of Double Product (Active Periods) Min within 7 days was $7683.06 \pm 1767.16$ which was changed to the mean $7726.47 \pm 1399.70$ at $12^{\text {th }}$ day. The mean value of Double Product (Active Periods) Max within 7 days was $13066.24 \pm 3007.52$ which was changed to the mean $13210.29 \pm 3109.18$ at $12^{\text {th }}$ day. The mean value of Double Product (Active Periods) Mean within 7 days was $10023.79 \pm 2206.40$ which was changed to the mean $10037.79 \pm 1665.92$ at $12^{\text {th }}$ day. The changes in min., max and mean double product (Active Periods) were not found to be statistically significant in between within 7 days and at $12^{\text {th }}$ day.

The mean value of Double Product (Passive Periods) Max within 7 days was $11065.65 \pm 2940.82$ which was changed to the mean $10925.68 \pm 2357.67$ at $12^{\text {th }}$ day. The mean value of Double Product (Passive Periods) Min within 7 days was $7846.82 \pm 2302.57$ which was changed to the mean $7768.47 \pm 1697.59$ at $12^{\text {th }}$ day. The mean value of Double Product (Passive Periods) Min within 7 days was $9243.91 \pm 2576.73$ which was changed to the mean $9162.03 \pm 1820.72$ at $12^{\text {th }}$ day. The changes in min., max and mean double product (Passive Periods) were also not found to be statistically significant in between within 7 days and at $12^{\text {th }}$ day.

TABLE I: Muscle FunCTION GRADING, SENSORY GRADING AND ASIA IMPAIRMENT SCALE (AIS) FOR PARAPLEGIA [17], [18]

\begin{tabular}{|c|c|}
\hline \multicolumn{2}{|c|}{ Muscle Function Grading } \\
\hline 0 & Total paralysis \\
\hline 1 & Palpable visible contraction \\
\hline 2 & $\begin{array}{l}\text { Active movement, full ROM against with gravity } \\
\text { eliminated }\end{array}$ \\
\hline 3 & Active movement, full ROM against gravity \\
\hline 4 & $\begin{array}{l}\text { Active movements, full ROM against gravity and } \\
\text { moderate resistance in a muscle specific position }\end{array}$ \\
\hline 5 & $\begin{array}{l}\text { Active movement, full ROM against gravity and full } \\
\text { resistance in a functional muscle position expected } \\
\text { from an otherwise unimpaired person. }\end{array}$ \\
\hline \multicolumn{2}{|c|}{ Sensory Grading } \\
\hline 0 & Absent \\
\hline 1 & $\begin{array}{l}\text { Altered, either decrease /impaired sensation or } \\
\text { hypersensitivity }\end{array}$ \\
\hline 2 & Normal \\
\hline \multicolumn{2}{|c|}{ Asia Impairment Scale (AIS) for paraplegia } \\
\hline $\mathrm{A}$ & $\begin{array}{l}\text { Complete } \rightarrow \text { No sensory or motor function is } \\
\text { preserved in the sacral segment s4-s5 }\end{array}$ \\
\hline $\mathrm{B}$ & $\begin{array}{l}\text { Sensory incomplete } \rightarrow \text { Sensory but not motor } \\
\text { function is preserved below the neurological level } \\
\text { preserved }\end{array}$ \\
\hline $\mathrm{C}$ & $\begin{array}{l}\text { Motor incomplete } \rightarrow \text { Motor function is preserved a } \\
\text { the most caudal sacral segment for voluntary anal } \\
\text { contraction }\end{array}$ \\
\hline $\mathrm{D}$ & Motor incomplete \\
\hline $\mathrm{E}$ & Normal \\
\hline
\end{tabular}

TABLE II: BASELINE CHARACTERISTICS OF PATIENTS

\begin{tabular}{|c|c|}
\hline & mean \pm SD \\
\hline Age & $33.79 \pm 11.05$ \\
\hline Gender & $\mathrm{n}(\%)$ \\
\hline Male & $27(79.4 \%)$ \\
\hline Female & $7(20.6 \%)$ \\
\hline \multicolumn{2}{|l|}{ Occupation } \\
\hline Student & $5(14.7 \%)$ \\
\hline Skilled Laborer & $4(11.8 \%)$ \\
\hline Unskilled Laborer & $16(47.1 \%)$ \\
\hline Farmer & $4(11.8 \%)$ \\
\hline Housewife & $5(14.7 \%)$ \\
\hline \multicolumn{2}{|l|}{ Mode of Injury } \\
\hline Fall from bike & $1(2.9 \%)$ \\
\hline Fall from height & $15(44.1 \%)$ \\
\hline Fall from stairs & $2(5.9 \%)$ \\
\hline Fall from tree & $6(17.6 \%)$ \\
\hline Fall of heavy object & $7(20.6 \%)$ \\
\hline RTA & $3(8.8 \%)$ \\
\hline \multicolumn{2}{|l|}{ Type of Injury } \\
\hline Complete & $22(64.7 \%)$ \\
\hline Incomplete & $12(35.3 \%)$ \\
\hline \multicolumn{2}{|l|}{ AIS Grade } \\
\hline $\mathrm{A}$ & $24(70.6 \%)$ \\
\hline B & $7(20.6 \%)$ \\
\hline $\mathrm{C}$ & $2(5.9 \%)$ \\
\hline $\mathrm{E}$ & $1(2.9 \%)$ \\
\hline \multicolumn{2}{|l|}{ BBI } \\
\hline Involuntary & $30(88.2 \%)$ \\
\hline Voluntary & $4(11.8 \%)$ \\
\hline \multicolumn{2}{|l|}{ Neurological } \\
\hline L1 & $15(44.1 \%)$ \\
\hline $\mathrm{L} 2$ & $1(2.9 \%)$ \\
\hline L3 & $1(2.9 \%)$ \\
\hline $\mathrm{T} 10$ & $5(14.7 \%)$ \\
\hline T11 & $3(8.8 \%)$ \\
\hline $\mathrm{T} 12$ & $4(11.8 \%)$ \\
\hline $\mathrm{T} 12, \mathrm{~L} 1$ & $1(2.9 \%)$ \\
\hline $\mathrm{T} 4$ & $1(2.9 \%)$ \\
\hline T8 & $2(5.9 \%)$ \\
\hline T9 & $1(2.9 \%)$ \\
\hline
\end{tabular}

TABLE III: THE CHANGES IN DIURNAL INDEX (DIASTOLE), DIURNAL INDEX (MAP), NIGHT DIPPING (SYSTOLE) AND MORNING SURGE (SYSTOLE)

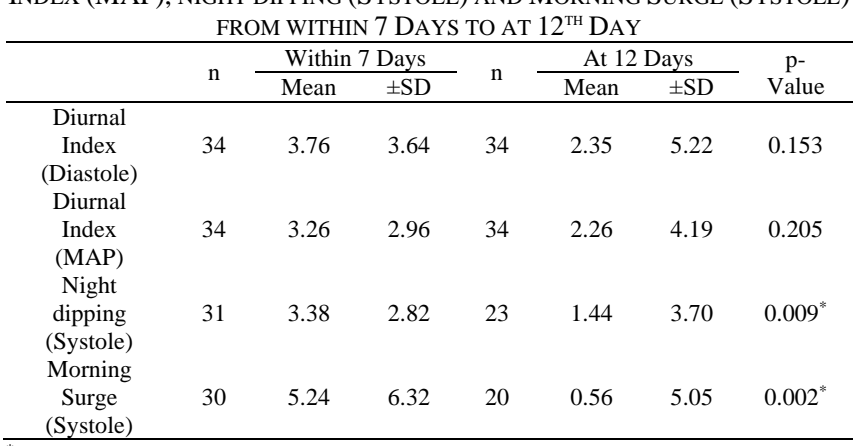
*=Significant $(\mathrm{p}<0.05)$.

TABLE IV: COMPARISON DBP (MAX), DBP (MIN.), SBP (MAX) AND SBP (MIN) IN BETWEEN WITHIN 7 DAYS AND AT $12^{\text {TH }}$ DAY

\begin{tabular}{lccccc}
\hline & \multicolumn{2}{c}{ Within 7 Days } & \multicolumn{2}{c}{ At 12 $2^{\text {th }}$ Day } & \multirow{2}{*}{ p-Value } \\
\cline { 2 - 5 } & Mean & \pm SD & Mean & \pm SD & \\
\hline DBP (Max) & 77.38 & 9.12 & 77.15 & 9.92 & 0.881 \\
SBP (Max) & 124.74 & 14.78 & 118.59 & 14.44 & $0.003^{*}$ \\
DBP (Min) & 62.38 & 9.44 & 61.44 & 9.17 & 0.633 \\
SBP (Min) & 105.26 & 13.43 & 100.06 & 9.89 & $0.033^{*}$ \\
\hline * Significant (p<0.05) & & & &
\end{tabular}


TABLE V: CHANGES IN MIN., MAX., AND MEAN DOUBle PRODUCT (AlL, ACTIVE PERIODS, AND PASSIVE PERIODS)

\begin{tabular}{|c|c|c|c|c|c|}
\hline & \multicolumn{2}{|c|}{ Within 7 Days } & \multicolumn{2}{|c|}{ At $12^{\text {th }}$ Day } & \multirow{2}{*}{$\begin{array}{c}\mathrm{p}- \\
\text { Value }\end{array}$} \\
\hline & Mean & $\pm \mathrm{SD}$ & Mean & $\pm \mathrm{SD}$ & \\
\hline $\begin{array}{l}\text { Double Product } \\
\text { (all) Min }\end{array}$ & 7231.76 & 1595.19 & 7473.00 & 1452.44 & 0.385 \\
\hline $\begin{array}{l}\text { Double Product } \\
\text { (all) Max }\end{array}$ & 13104.85 & 3046.42 & 13224.53 & 3100.06 & 0.857 \\
\hline $\begin{array}{l}\text { Double Product } \\
\text { (all) mean }\end{array}$ & 9761.65 & 2290.68 & 9831.82 & 1693.83 & 0.855 \\
\hline $\begin{array}{c}\text { Double Product } \\
\text { (Active Periods) } \\
\text { Min }\end{array}$ & 7683.06 & 1767.16 & 7726.47 & 1399.70 & 0.883 \\
\hline $\begin{array}{c}\text { Double Product } \\
\text { (Active Periods) } \\
\text { Max }\end{array}$ & 13066.24 & 3007.52 & 13210.29 & 3109.18 & 0.826 \\
\hline $\begin{array}{c}\text { Double Product } \\
\text { (Active Periods) } \\
\text { mean }\end{array}$ & 10023.79 & 2206.40 & 10037.79 & 1665.92 & 0.969 \\
\hline $\begin{array}{c}\text { Double Product } \\
\text { (Passive } \\
\text { Periods) Min }\end{array}$ & 7846.82 & 2302.57 & 7768.47 & 1697.59 & 0.832 \\
\hline $\begin{array}{c}\text { Double Product } \\
\text { (Passive } \\
\text { Periods) Max }\end{array}$ & 11065.65 & 2940.82 & 10925.68 & 2357.67 & 0.800 \\
\hline $\begin{array}{l}\text { Double Product } \\
\text { (Passive } \\
\text { Periods) mean }\end{array}$ & 9243.91 & 2576.73 & 9162.03 & 1820.72 & 0.852 \\
\hline
\end{tabular}

\section{DISCUSSION}

Over the past decade, numbers of spinal cord injury patient are increasing at a very high rate and also, the cardiovascular morbidity and mortality among them. Both of them possess a great clinical and economic burden over the society. Previous studies have illustrated that cardiovascular changes in spinal cord injury increases the risk of cardiovascular morbidity and mortality [14]. Possible cause for this may be the Autonomic Dysreflexia, spinal shock, increase in shear stress of blood vessels and cessation of normal daily blood pressure fluctuations which are seen in healthy individuals [14], [19]. Also, these patients live unhealthy lifestyle which includes smoking, physical inactivity, and an unhealthy diet. Long term ambulatory loss in these patients leads to numerous cardiovascular risks like Coronary Artery Disease (CAD), hypertension, cardiovascular disease, valvular disease, and dysarrhythmias [20]. SCI decreases autonomic neural control over cardiovascular function with the most severe effects on BP control when the injury occurs above the $6^{\text {th }}$ thoracic segment [21]. The change in blood pressure rhythm in tetraplegic subjects, show a loss of nocturnal dip [22]. The level of lesion plays a major role in the preservation of circadian rhythm. The SCI subjects with either low thoracic or high thoracic lesion show a preserved nocturnal dip, compared with cervical SCI lesion [22]. Studies conducted in past few years have proven that Ambulatory blood pressure monitoring technique helps in recording multiple blood pressure readings over 24 hour period, whether the patient is awake or asleep. Thus, proving itself as a valuable instrument for knowing Cardiovascular risk in patients with Spinal Cord Injury [23].

In the present study, it was seen that maximum number of cases falls in the age group of 21-30 years. The findings coincide with previous data available to us which shows that majority of cases of SCI are between the age group of 16-30 years [24]. The probable cause for such finding may be that this age group comprise of most active individuals. These people spend much of their time travelling on roads and are thus, prone to accidents. Also, this age group comprises laborers working at construction sites that are prone to fall and get spinal cord injury.

In our study, it was observed that majority of cases were males as compared to females. Similarly, previous study shows that the males are more prone than females to develop traumatic paraplegia at any age group [25]. The probable reason for this increased male to female ratio might be that majority of women are dealing with household work only and males are more active in outside work.

In the present study, distribution of patients according to their occupation depicted that most of the cases were Labourers and mode of injury was fall from height. The data available from previous studies was not in agreement with our observations which showed that automobile crashes are the major cause of SCI [26]. The reason might be that as the present study was conducted in government set up and majority of the patients i.e., laborers coming to the hospital belongs to lower socioeconomic status.

In the present study, maximum number of cases lies in AISA than AIS- B grading of traumatic paraplegia patients. Various previous studies demonstrated that the majority of traumatic paraplegia patients fall under A grade of AIS scoring [14], [27].

In the present study, distribution of subjects according to Bladder and Bowel involvement shows that majority of cases have involuntary control. Similar findings were observed in previous studies which demonstrated that bladder becomes atonic, and conscious awareness of bladder filling is lost [28]. This occurs due to interruption of the neural conduction below the level of pons and thus abolish micturition reflex, which causes retention of urine in spinal cord injury patients.

In the present study, the majority of cases have L1 level and T12 was second most common neurological involvement. A study demonstrated that the most common level of the spinal cord injury is cervical spine [29], [30]. The probable cause for this may be due to the maximum impact of injury on L1because it is present at end of kyphosis and beginning of lordosis of spine.

In our study, the frequencies abnormal diurnal index was significantly increased with time pass. This change in circadian BP may be due to the sympathetic nervous system. During sleep, the sympathetic nervous system remains quiescent whereas, in the early morning, BP rises sharply due to activation of same [14]. Other possible cause which might not be that significant is, during the sleep BP cuff inflate and deflate which causes disturbance in sleep of the patient and further reduces the BP fluctuations due to awakening [31]. Also, in patients of SCI physical activity is lost due to paralysis of lower limbs which further leads to loss of normal circadian fluctuations in BP [32], [33]. Previous study shows that circadian BP changes are also contributed by mental and physical activities of the individual [34]. Another study also found that in patients with thoracic spinal cord injury, Diurnal variation of blood pressure is lost. The above findings matched with our result [35]. The loss of diurnal variation of blood pressure leads to hemodynamic changes resulting in cardiovascular diseases like hypertension, stroke, orthostatic hypotension, valvular disease etc. Thus, resulting in increased risk of cardiovascular morbidity and mortality in SCI patients. 
In the present study, we found significant positive correlation of SBP in diurnal Index between within $7^{\text {th }}$ day and $12^{\text {th }}$ day of ABPM monitoring. No significant correlation was seen in DBP and mean arterial pressure in diurnal index between within $7^{\text {th }}$ day and $12^{\text {th }}$ day of ABPM monitoring. In best of my knowledge, I was unable to find any relevant data about SBP, DBP and MAP in Diurnal Index separately in patients with SCI.

It is the differences of mean blood pressure (\%) between awake and sleep period. In normal healthy individuals a rise in BP is seen upon awakening in the morning during ambulatory BP monitoring. The underlying mechanisms for this surge in BP in the morning are change in posture, activation of sympathetic nervous system, renin-aldosterone system activation, and cortisol system activation [36]. In the present study we found that within $7^{\text {th }}$ day of ABPM monitoring 4 patients shown absence of morning surge while 30 were having normal morning surge. On $12^{\text {th }}$ day of ABPM monitoring, number of patients showing absence of morning surge increased to 13. A significant positive correlation of morning surge was seen between within $7^{\text {th }}$ day and $12^{\text {th }}$ day of ABPM monitoring. The possible cause for this might be the loss of supraspinal and autonomic nervous system control over the cardiovascular system.

In our study we found significant positive correlation of systolic blood pressure within $7^{\text {th }}$ day and $12^{\text {th }}$ day of ABPM monitoring. According to pathophysiology of SCI, immediately after the spinal cord injury blood pressure rises then as few days passes by, systolic blood pressure keeps on falling due to failure of compensatory mechanism responsible for vasoconstriction. The compensatory mechanism includes changes in sympathetic activity within large vascular beds, like skeletal muscle and splanchnic circulation and decreased venous return resulting in decreased cardiac output following low systolic blood pressure. This reduced systolic blood pressure improves within days to weeks due to activation of compensatory mechanisms like spinal sympathetic reflexes, skeletal muscular tone, and rennin-angiotensin-aldosterone system and increased the blood pressure after few days of injury [36]. The probable cause for this change in blood pressure might be spinal shock which leads to loss of supraspinal modulation, altered spinal neurotransmitters balance, sympathetic system failure and parasympathetic system dominance [36]. The systolic blood pressure levels remain normal with circadian rhythm in patients with paraplegia which does match with our findings [37].

In this study we did not found any significant correlation of diastolic blood pressure within $7^{\text {th }}$ day and $12^{\text {th }}$ day of ABPM monitoring in patients of paraplegia. Nitsche et, al conducted a study and found that systolic blood pressure levels remain normal with circadian rhythm in patients with paraplegia which matches with our findings [37]

In this study the normal dipping pattern was found 31 $(91.18 \%)$ patients at $7^{\text {th }}$ day and $23(67.65 \%)$ at $12^{\text {th }}$ day of ABPM monitoring. The possible cause for this nocturnal dipping in blood pressure might be the inhibition of Sympathetic Nervous System from supraspinal centers in brain. As we know that paraplegia patients are unable to do any daily physical activity due to paralysis of lower limbs, thus sympatho-excitatory drive is absent in these patients resulting in reduced day time blood pressure. This results in loss of nocturnal dip. Previously a study found that in patients with thoracic spinal cord injury, night dipping in blood pressure is lost. The above findings matched with our result [35]. Previous study showed that paraplegia patients have preserved nocturnal dip while tetraplegia patients have loss of nocturnal dip in ABPM which is not in agreement with our findings [14].

\section{CONCLUSION}

In the present study we can conclude that traumatic paraplegic patients have altered diurnal index, morning surge, night dipping and systolic blood pressure on APBM monitoring. Looking at the current scenario of increasing risk of developing cardiovascular morbidity and mortality in traumatic paraplegia patients, it is of great importance to identify a simple, cost effective, non-invasive and reliable marker with proper understanding of their relationship with disease for screening purpose.

\section{REFERENCES}

[1] Teasell RW, Arnold MA, Krassioukov A, Delaney GA. Cardiovascular consequences of loss of supraspinal control of the sympathetic nervous system. Arch Phys Med Rehabil. 2000;81(4): 506-516.

[2] Mathias CJ. Orthostatic hypotension and paroxysmal hypertension in humans with high spinal cord injury. Prog Brain Res. 2006;152: 231243.

[3] Garstang SV, Miller-Smith SA. Autonomic nervous system dysfunction after spinal cord injury. Phys Med Rehabil Clin N Am. 2007; 18: 275-296.

[4] Cragg JJ, Noonan VK, Krassioukov A, Borisoff J. Cardiovascular disease and spinal cord injury: results from a National Population Health Survey. Neurology 2013; 81:723-728.

[5] Dance DL, Chopra A, Campbell K, Ditor DS, Hassouna M, Craven BC. Exploring daily blood pressure fluctuations and cardiovascular risk among individuals with motor complete spinal cord injury: a pilot study. J Spinal Cord Med 2017; 40:405-414.

[6] Hwang M, Zebracki K, Betz RR, Mulcahey MJ, Vogel LC. Normative blood pressure and heart rate in pediatric spinal cord injury. Top Spinal Cord Inj Rehabil. 2013 Spring;19(2):87-95.

[7] Claydon VE, Krassioukov AV. Clinical correlates of frequency analyses of cardiovascular control after spinal cord injury. Am J Physiol Heart Circ Physiol 2008; 294:H668-H678.

[8] West CR, Mills P, Krassioukov AV. Influence of the neurological level of spinal cord injury on cardiovascular outcomes in humans: a metaanalysis. Spinal Cord 2012; 50:484-492.

[9] Nitsche B, Perschak H, Curt A, Dietz V. Loss of circadian blood pressure variability in complete tetraplegia. J Hum Hypertens. 1996;10:311-317.

[10] Fitzharris M, Cripps RA, Lee BB. Estimating the global incidence of traumatic spinal cord injury. Spinal Cord. 2014;52:117-22.

[11] Singh A, Tetreault L, Kalsi-Ryan S, Nouri A, Fehlings MG. Global prevalence and incidence of traumatic spinal cord injury. Clin Epidemiol. 2014;6:309-31

[12] Spinal cord injury [Internet]. World Health Organization. 2013 [cited 2019 Aug 30]. https://www.who.int/news-room/factsheets/detail/spinal-cord-injury.

[13] Cardenas DD, Hoffman JM, Kirshblum S, McKinley W. Etiology and incidence of rehospitalization after traumatic spinal cord injury: a multicenter analysis. Arch Phys Med Rehabil. 2004;85:1757-63.

[14] Hubli M, Krassioukov AV. Ambulatory blood pressure monitoring in spinal cord injury: clinical practicability. J Neurotrauma. 2014;31:78997.

[15] Kirshblum SC, Burns SP, Biering-Sorensen F, Donovan W, Graves DE, Jha A, Johansen M, Jones L, Krassioukov A, Mulcahey MJ, Schmidt-Read M, Waring W. International standards for neurological classification of spinal cord injury (revised 2011). J Spinal Cord Med. 2011;34:535-46.

[16] Griepp EB, Di Luozzo G, Schray D, Stefanovic A, Geisbüsch S, Griepp RB. The anatomy of the spinal cord collateral circulation. Ann Cardiothorac Surg. 2012;1:350-7. 
[17] Kirshblum SC, Burns SP, Biering-Sorensen F, Donovan W, Graves DE, Jha A, Johansen M, Jones L, Krassioukov A, Mulcahey MJ, Schmidt-Read M, Waring W. International standards for neurological classification of spinal cord injury (revised 2011). J Spinal Cord Med. 2011;34:535-46.

[18] Roberts TT, Leonard GR, Cepela DJ. Classifications In Brief: American Spinal Injury Association (ASIA) Impairment Scale. Clin Orthop Relat Res. 2017;475:1499-1504.

[19] Allen KJ, Leslie SW. Autonomic Dysreflexia. 2020 Sep 25. In: StatPearls [Internet]. Treasure Island (FL): StatPearls Publishing; 2020 Jan-. PMID: 29494041.

[20] Groah SL, Weitzenkamp D, Sett P, et al: The relationship between neurological level of injury and symptomatic cardiovascular disease risk in the aging spinal injured. Spinal Cord 2001;39:310-7.

[21] Linsell C.R., Lightman S.L., Mullen P.E., Brown M.J., and Causon R.C. (1985). Circadian rhythms of epinephrine and norepinephrine in man. J. Clin. Endocrinol. Metab. 60, 1210-1215.

[22] Rosado-Rivera D, Radulovic M, Handrakis JP, Cirnigliaro CM, Jensen AM, Kirshblum S, Bauman WA, Wecht JM. Comparison of 24-hour cardiovascular and autonomic function inparaplegia, tetraplegia, and control groups: implications for cardio-vascular risk. J. Spinal Cord Med. 2011;34:395-403.

[23] Prasad K. (2000). Blood pressure and its control mechanism. In: Textbook of Angiology. Chang J. (ed). Springer: New York, pps. 4654.

[24] Toda M, Nakatani E, Omae K, Fukushima M, Chin T. Age-specific characterization of spinal cord injuries over a 19-year period at a Japanese rehabilitation center. PLoS One. 2018 Mar 29;13(3):e0195120.

[25] Singh A, Tetreault L, Kalsi-Ryan S, Nouri A, Fehlings MG. Global prevalence and incidence of traumatic spinal cord injury. Clin Epidemiol. 2014 Sep 23;6:309-31.

[26] Chen Y, Tang Y, Vogel LC, Devivo MJ. Causes of spinal cord injury. Top Spinal Cord Inj Rehabil. 2013 Winter;19(1):1-8.

[27] Van Middendorp JJ, Hosman AJ, Pouw MH; EM-SCI Study Group, Van de Meent H. ASIA impairment scale conversion in traumatic SCI: is it related with the ability to walk? A descriptive comparison with functional ambulation outcome measures in 273 patients. Spinal Cord. $2009 \mathrm{Jul} ; 47(7): 555-60$.
[28] Taweel WA, Seyam R. Neurogenic bladder in spinal cord injury patients. Res Rep Urol. 2015 Jun 10;7:85-99. doi: 10.2147/RRU.S29644.

[29] Alizadeh A, Dyck SM, Karimi-Abdolrezaee S. Traumatic Spinal Cord Injury: An Overview of Pathophysiology, Models and Acute Injury Mechanisms. Front Neurol. 2019 Mar 22;10:282.

[30] Hachem LD, Ahuja CS, Fehlings MG. Assessment and management of acute spinal cord injury: from point of injury to rehabilitation. J Spinal Cord Med.2017;40:665-75.

[31] Yano Y, Kario K. Nocturnal blood pressure and cardiovascular disease: a review of recent advances. Hypertens. Res. 2012;35:695-70.

[32] Mallion JM, Baguet JP, Mancia G. European societyof hypertension scientific newsletter: clinical value of ambulatoryblood pressure monitoring. J. Hypertens. 2006;24:2327-2330.

[33] Sabour H, Norouzi-Javidan A, Soltani Z, Mousavifar SA, Latifi S, Emami-Razavi SH, Ghodsi SM. The correlation between dietary fat intake and blood pressure among people with spinal cord injury. Iranian Journal of Neurology. 2016;15:121.

[34] Kawano Y. Diurnal blood pressure variation and related behavioral factors. Hypertens Res. 2011;34:281-5.

[35] Lee ES, Joo MC. Prevalence of Autonomic Dysreflexia in Patients with Spinal Cord Injury above T6. Biomed Res Int. 2017;2017:2027594.

[36] Popa C, Popa F, Grigorean VT, Onose G, Sandu AM, Popescu M, Burnei G, Strambu V, Sinescu C. Vascular dysfunctions following spinal cord injury. J Med Life. 2010;3:275-85.

[37] Gondim FA, Lopes AC Jr, Oliveira GR, Rodrigues CL, Leal PR, Santos AA, Rola FH. Cardiovascular control after spinal cord injury. Curr Vasc Pharmacol. 2004;2:71-9.

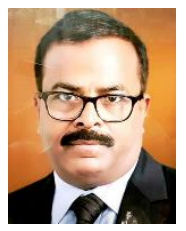

Narsingh Verma is Professor Department of Physiology (since 16 Yrs) King Georges Medical University, Vice Dean Faculty of Medicine, Vice Dean Student Welfare, Faculty In charge MCI Cell KGMU Lucknow / Former Medical Superintendent GM \& Associated Hospitals KGMU Lucknow (for 5 years) \& Former Head Department of Transfusion Medicine KGMU Lucknow (4 Years) Faculty in charge Media Cell. 